\title{
Patrizia Caraffi, Christine de Pizan e Boccaccio: silenzio e crudeltà
}

\section{Maria Colombo Timelli}

\section{(2) OpenEdition}

1 Journals

\section{Édition électronique}

URL : http://journals.openedition.org/studifrancesi/35721

DOI : 10.4000/studifrancesi.35721

ISSN : 2421-5856

Éditeur

Rosenberg \& Sellier

\section{Édition imprimée}

Date de publication : 1 juillet 2005

Pagination : 133

ISSN : 0039-2944

\section{Référence électronique}

Maria Colombo Timelli, « Patrizia Caraffi, Christine de Pizan e Boccaccio: silenzio e crudeltà », Studi Francesi [En ligne], 145 (XLIX | I) | 2005, mis en ligne le 30 novembre 2015, consulté le 18 avril 2021. URL : http://journals.openedition.org/studifrancesi/35721; DOI : https://doi.org/10.4000/ studifrancesi.35721 


\title{
Patrizia Caraffi, Christine de Pizan e Boccaccio: silenzio e crudeltà
}

\author{
Maria Colombo Timelli
}

\section{RÉFÉRENCE}

PATRIZIA CARAFFI, Christine de Pizan e Boccaccio: silenzio e crudeltà, in: P.C., Figure femminili del sapere (XII-XV secolo), Roma, Carocci, 2003 («Biblioteca Medievale. Saggi», 12), pp.

123-138.

1 Si Christine reprend trois nouvelles du Décameron (Bernabo da Genova, Tancredi prinze di Salerno, I fratelli dell'Isabetta), elle les réécrit en profondeur, en en adaptant le sens à sa propre vision de la vie et du monde: elle réinterprète donc les récits du point de vue des protagonistes, victimes de la cruauté des hommes. Le contexte social est aussi modifié: celui de Christine est un monde courtois, où les femmes représentent la seule possibilité de progrès et de rachat, malgré leur condition de soumission et au-delà du silence qui leur est imposé. 